\title{
Detection of glutamine synthetase activity in marine phytoplankton: optimization of the biosynthetic assay
}

\author{
Steven L. Bressler ${ }^{*}$ and Saiyed I. Ahmed \\ Department of Oceanography, WB-10, University of Washington, Seattle, Washington 98195, USA
}

\begin{abstract}
A comprehensive study of the key ammonium-assimilating enzyme, glutamine synthetase (GS), was made in a variety of marine phytoplankton. GS activity was detected in 13 out of the 15 species examined comprising 6 algal classes. Both the biosynthetic GS reaction as well as the transferase reaction were measured with phytoplankton extracts for comparative purposes. In evaluating the differences between the 2 assays it was found that the biosynthetic assay was more sensitive than the transferase assay in terms of final product formed/assay. The transferase assay yielded a more stable fincl product but the reaction is not specific for GS (Meister, 1974). A series of kinetic studies on the GS enzyme were carried out on a number of marine species. These studies included the determination of the $\mathrm{pH}$ optimum, linearity of the reaction with time, apparent energies of activation $\left(\mathrm{E}_{\mathrm{a}}\right)$ and apparent $\mathrm{K}_{\mathrm{m}}$ values for the substrates: $\mathrm{NH}_{4}{ }^{+}$, glutamate and ATP. In addition, the optimum requirement for the divalent cation, $\mathrm{Mg}^{++}$was ascertained. The most significant finding of these studies was the broad distribution of GS activity in marine phytoplankton. The apparent $\mathrm{K}_{\mathrm{m}}$ values for ammonium were in the micromolar range. This is in marked contrast to earlier observations of the requirement of glutamate dehydrogenase (GDH), an alternate ammonium-assimilating enzyme, which has been shown to have a $\mathrm{K}_{\mathrm{m}}$ for ammonium ions in the millimolar range. These data support the view that GS is the primary ammonium-assimilating enzyme in phytoplankton found in areas of intermittent nitrogen supply.
\end{abstract}

\section{INTRODUCTION}

It is now widely accepted that nitrogen is the primary limiting nutrient controlling marine phytoplankton growth and productivity in many temperate and tropical marine environments (Thomas, 1966, 1969; Ryther and Dunstan, 1971; Dugdale, 1976). Accordingly, the study of both uptake and assimilation of nitrogen is of paramount importance in understanding nitrogen utilization by phytoplankton and assessing the dynamics of primary productivity. The direct catalytic action of certain key enzymes regulates growth and assimilation of nitrogen, and the dynamic action of these enzymes must be directly assessed to fully comprehend and evaluate the processes involved.

\footnotetext{
- Present address: Department of Botany, KB-15, University of Washington, Seattle, Washington 98195, USA
}

Previously, the enzyme glutamate dehydrogenase $(\mathrm{GDH})$ was generally accepted as the primary ammonium-assimilating enzyme (Eq. 1) in a variety of plant and animal cells (Miflin and Lea, 1976, 1980; Stewart et al., 1980).

2-oxoglutarate $+\mathrm{NH}_{3}+\mathrm{NAD}(\mathrm{P}) \mathrm{H} \underset{\mathrm{GDH}}{\rightleftarrows}$ L-glutamate $+\mathrm{NAD}^{+}\left(\right.$or $\left.\mathrm{NADP}^{+}\right)+\mathrm{H}_{2} \mathrm{O}$

However, it was not until the discovery by Tempest

Abbreviations: ATP, adenosine triphosphate; ADP, adenosine diphosphate, $F_{\text {ox }}$, ferredoxin, oxidized; $F d_{r e d}$, ferredoxin, reduced; GDH, glutamate dehydrogenase; GS, glutamine synthetase; GOGAT, glutamine oxoglutarate aminotransferase, also referred to by its trivial name glutamate synthase; $\mathrm{NAD}^{+}$, nicotinamide adenine dinucleotide; $\mathrm{NADP}^{+}$. nicotinamide adenine dinucleotide phosphate; NADH, nicotinamide adenine dinucleotide, reduced; $N A D P H$, nicotinamide adenine dinucleotide phosphate, reduced; $P_{1}$, inorganic phosphate 
et al. (1970) of the occurrence of the enzyme glutamate synthase (GOGAT), that the importance of an alternate route of ammonium assimilation via mediation of the enzymes glutamine synthetase (GS) coupled with the glutamate synthase (GOGAT) enzyme was fully realized (Eq. 2 and 3 ).

L-glutamate $+\mathrm{NH}_{3}+\mathrm{ATP} \frac{\mathrm{GS}}{\underset{(\longleftarrow)}{\mathrm{Mg}^{++}} \text {L-glutamine }+}$

$\mathrm{ADP}+\mathrm{P}_{\mathrm{i}}+\mathrm{H}_{2} \mathrm{O}$

L-glutamine + 2-oxoglutarate $+\mathrm{NAD}(\mathrm{P}) \mathrm{H}$ (or $\mathrm{Fd}_{\text {red }}$ ) $\stackrel{\mathrm{GOGAT}}{\longrightarrow} 2$ glutamate $+\mathrm{NAD}(\mathrm{P})^{+}\left(\mathrm{or} \mathrm{Fd}_{\mathrm{ox}}\right)$

Recently, the enzyme GS in the GS/GOGAT pathway of ammonium-assimilation has been reported in a variety of algal and cyanobacterial cells as well as in animal cells (Meister, 1974; Lea and Miflin, 1975; Falkowski and Rivkin, 1976; Meeks et al., 1977; Hipkin and Syrett, 1977; Edge and Ricketts, 1978; Turpin and Harrison, 1978; McKenzie et al., 1979; Tischner and Hüttermann, 1980; Sornarajah and Holdsworth, 1981). Almost invariably, GS activity has been found to exhibit a very low $\mathrm{K}_{\mathrm{m}}$ for ammonium (Miflin and Lea, 1980; Stewart et al., 1980; Tischner and Hüttermann, 1980; Cullimore and Sims, 1981; Paone and Stevens, Jr., 1981).

As the availability of ammonium is limited in the euphotic zone of the marine environment, it appeared to us that marine phytoplankton would serve as ideal test organisms in which to study the distribution and function of the GS enzyme system. This view was reinforced by our earlier studies on GDH (Ahmed et al., 1977) which was found to exhibit a very low affinity for ammonium. Our subsequent detailed studies on the role of GDH in ammonium assimilation in a dominant marine diatom, Skeletonema costatum, (Dortch et al., 1979) as well as the studies by Falkowski and Rivkin (1976) and Turpin and Harrison (1978) further support this view. Thus while GDH activity might be of prime importance in nitrogen assimilation in organisms such as Caulerpa simpliciuscula (Gayler and Morgan, 1976; McKenzie et al., 1979) and in Stichococcus bacillaris (Everest and Syrett, in press), it appears to play only a secondary role in marine phytoplankton. We report here the detection of glutamine synthetase activity in a wide variety of marine phytoplankton, all exhibiting much greater apparent affinity for scavenging ammonium ions than reported for GDH. GS activities were determined by assaying both the biosynthetic and transferase reaction. The assay conditions for the biosynthetic reaction were optimized. While it may be argued that in vitro $\mathrm{K}_{\mathrm{m}}$ values may not always be reflective of in vivo conditions, the consistency of these findings point to a finely tuned accommodation between environmental availability of a substrate and the corresponding response of an enzyme system to mobilize its resources to scavenge efficiently for a scarce nutrient such as nitrogen.

\section{MATERLALS AND METHODS}

\section{Chemicals}

All inorganic chemicals were reagent grade. Adenosine triphosphate (ATP), adenosine diphosphate (ADP), imidazole, hydroxylamine and $\gamma$-glutamylhydroxamate were all obtained from Sigma Chemical Co. (St. Louis, Mo.).

\section{Algal cultures}

Batch cultures were grown on artificial seawater medium (Pavlou, 1972). The only nitrogen source was $\mathrm{NH}_{4} \mathrm{Cl}$ at a concentration of $100 \mu \mathrm{M}$. Table 1 lists the algal species cultured. The majority of these cultures were obtained from the University of Washington Phytoplankton Culture Collection, School of Oceanography and the Department of Botany. The cultures were maintained as semi-continuous cultures in 1-1 and 3-1 flat-bottomed boiling flasks at $16 \mathrm{C}^{\circ} \pm 0.5 \mathrm{C}^{\circ}$ under a continuous irradiance of $150 \mu \mathrm{Em}^{-2} \mathrm{~s}^{-1}$ supplied by four, 48-inch very-high-output (VHO) fluorescent lights (Sylvania \#F48T12-D-VHO). The overhead fluorescent lights passed through a $3.2 \mathrm{~mm}$ thick sheet of blue plexiglass (Rohm and Haas \#2069). This filter arrangement has been reported to simulate the spectral quality of light at $5 \mathrm{~m}$ in coastal water (Harrison et al., 1977).

The cultures were examined frequently with a light microscope for possible bacterial contamination. Any non-axenic cultures were discarded. Cells were harvested during the exponential phase of growth except in the case of Isochrysis galbana in which senescent cells were assayed because they exhibited greater levels of GS activity.

\section{Preparation of cell-free extract}

A $500 \mathrm{ml}$ portion of an exponentially growing culture was filtered onto a $47 \mathrm{~mm}$ Whatman 934-AH glass fiber filter. The filter was homogenized in $2 \mathrm{ml}$ of cold extraction buffer $(0.01 \mathrm{M}$ imidazole, $2.0 \mathrm{mM} \beta$-mercatoethanol and $0.01 \mathrm{M} \mathrm{MnCl}_{2} \cdot 4 \mathrm{H}_{2} \mathrm{O}$ ) in a PotterElvehjem tissue homogenizer for $5 \mathrm{~min}$ while being chilled on an ice bath. The $\mathrm{pH}$ was adjusted to 7.0 with $1 \mathrm{~N} \mathrm{HCl}$. The homogenized suspension was centrifuged at $20400 \times \mathrm{g}$ in a Sorvall RC 2-B refrigerated 
centrifuge. The supernatant was carefully decanted and stored on ice. This fraction is referred to as the cellfree extract.

\section{Enzyme assays}

Biosynthetic assay

In the biosynthetic reaction (Eq. 2), glutamine synthetase (GS) activity was measured spectrophotometrically by determining the amount of inorganic phosphate liberated. Our methodology was a slight modification of the method outlined by Shapiro and Stadtman (1970) and Falkowski and Rivkin (1976). The biosynthetic assay measures the activity of the enzyme GS by using its physiological substrates. It is important to point out that there are limitations with this assay, especially when assaying crude enzyme extracts. The numerous phosphatases and ATPases found in culture extracts can also yield a part of the inorganic phosphate measured. Therefore, as an internal control, a minus substrate blank (minus glutamate) was always included with each assay. The minus substrate blank values were subtracted from the values obtained with the complete mixture. Similarly, from time to time other controls such as a minus enzyme blank and an inactivated enzyme blank were also utilized to obtain the correct value of the GS-catalyzed product formation.

Presently laboratory studies are underway using radiolabelled ${ }^{14} \mathrm{C}$-glutamate for the measurement of the GS activity, the results of which will be described elsewhere. This radiometric assay for GS has previously been described by Pahuja and Reid (1982).

The biosynthetic reaction mixture contained:

$200 \mu$ Imidazole- $\mathrm{HCl}$ buffer 1.0 M, pH 7.0

$10 \mu \mathrm{l} \mathrm{NH} \mathrm{Nl}_{4} 10.0 \mathrm{mM}$

$50 \mu \mathrm{A}$ ATP $60.0 \mathrm{mM}, \mathrm{pH} 7.0$

$50 \mu \mathrm{l} \mathrm{MgCl}_{2} \cdot 6 \mathrm{H}_{2} \mathrm{O} 1.67 \mathrm{M}$

$50 \mu \mathrm{l} \mathrm{Na-glutamate} 1.0 \mathrm{M}, \mathrm{pH} 7.0$

$100 \mu l$ cell-free extract

$\overline{460 \mu \mathrm{l} \text { total volume of reaction mixture }}$

These were the concentrations of all the substrates when we began to optimize the assay. The reaction was initiated by the addition of $100 \mu \mathrm{l}$ of cell-free extract. After an incubation period of $30 \mathrm{~min}$ at $25^{\circ} \mathrm{C}$, the reaction was stopped by the addition of $1.8 \mathrm{ml}$ of $\mathrm{FeSO}_{4} \cdot 7 \mathrm{H}_{2} \mathrm{O}$ solution $\left(0.8 \% \mathrm{w} / \mathrm{v}\right.$ in $\left.0.015 \mathrm{~N} \mathrm{H}_{2} \mathrm{SO}_{4}\right)$, and the tubes were vortexed and placed on an ice bath. Thereafter, $0.15 \mathrm{ml}$ of the color-forming reagent ammonium molybdate $\left(6.6 \% \mathrm{w} / \mathrm{v}\right.$ in $\left.7.5 \mathrm{~N} \mathrm{H}_{2} \mathrm{SO}_{4}\right)$ was added. The reaction tubes were again vortexed vigor- ously, placed on an ice bath and immediately read at $850 \mathrm{~nm}$ on a Beckman DU spectrophotometer equipped with a flow-through cell.

\section{Transferase assay}

GS activity was measured by assaying for the formation of $\gamma$-glutamylhydroxamate according to the reaction:

L-glutamine $+\mathrm{NH}_{2} \mathrm{OH} \underset{\mathrm{ADP}, \text { arsenate }}{\stackrel{\mathrm{GS}, \mathrm{Mn}^{++}}{\mathrm{A}}} \gamma$-glutamyl-

hydroxamate $+\mathrm{NH}_{3}$

The transferase reaction mixture contained:

$480 \mu \mathrm{l} 1.0 \mathrm{M}$ Imidazole-HCl buffer، $\mathrm{pH} 7.3$

$300 \mu \mathrm{l} 0.1 \mathrm{M}$ glutamine

$30 \mu \mathrm{l} 0.01 \mathrm{M} \mathrm{MnCl}_{2}$

$40 \mu \mathrm{l} 0.01 \mathrm{M}$ ADP, pH 7.3

$20 \mu \mathrm{l} 1.0 \mathrm{M} \mathrm{K}$-arsenate

$30 \mu \mathrm{l} 2.0 \mathrm{M}$ Hydroxylamine

$100 \mu \mathrm{l}$ cell-free extract

$\overline{1000 \mu l \text { total volume of the reaction mixture }}$

The actual assay procedure followed (Shapiro and Stadtman, 1970) was similar to the biosynthetic assay procedure except in this case, after incubation, the reaction was stopped by the addition of $1.0 \mathrm{ml}$ of a mixture of $4.0 \mathrm{ml} 10 \% \mathrm{FeCl}_{3}, 1.0 \mathrm{ml} 24 \%$ trichloroacetic acid, $0.50 \mathrm{ml} 6 \mathrm{~N} \mathrm{HCl}$ and $6.5 \mathrm{ml}$ double-distilled water. After stopping the reaction, the tubes were vortexed and their absorbances at $540 \mathrm{~nm}$ read on a Beckman DU spectrophotometer. Occasionally a precipitate formed. In such cases the samples were centrifuged at $3000 \times \mathrm{g}$ for $5 \mathrm{~min}$ to remove turbidity, the supernatant carefully decanted and its absorbance at $540 \mathrm{~nm}$ measured.

\section{Enzyme activity}

Specific activity for the biosynthetic reaction was computed in terms of micromoles inorganic phosphate liberated $(\mathrm{min})^{-1}(\mathrm{mg} \text { protein })^{-1}$ of the cell-free extract. The values for the transferase reaction were computed in terms of nanomoles $\gamma$-glutamylhydroxamate formed/assay. For comparative purposes, the biosynthetic/transferase ratios were computed in terms of nanomoles of final product formed/assay. This approach was justified because the amount of biomass filtered, the volume of extract used, and the incubation times were equivalent for all analyses. Protein determination was made according to Bradford (1976). 
Table 1. Distribution of GS activity in exponentially growing cultures of marine phytoplankton. Isochrysis galbana cultures were in the senescent phase of growth. Biosynthetic GS activity is in terms of nmoles of $\mathrm{PO}_{4}^{3-}$ liberated per assay $(+=1-20$ nmoles $\mathrm{PO}_{4}{ }^{3-} ;++>20$ nmoles $\mathrm{PO}_{4}{ }^{3-} ;-<1$ nmole $\mathrm{PO}_{4}{ }^{3-}$ ). Transferase GS activity is in terms of nmoles of $\gamma$-glutamylhydroxamate formed per assay $(+=1-10$ nmoles $\gamma$-glutamylhydroxamate; $++>10$ nmoles $\gamma$-glutamylhydroxamate; $-<1$ nmole $\gamma$ glutamylhydroxamate)

\begin{tabular}{|c|c|c|c|}
\hline Species & $n$ & $\begin{array}{l}\text { GS activity } \\
\text { Biosynthetic }\end{array}$ & Transferase \\
\hline \multicolumn{4}{|l|}{ Bacillariophyceae } \\
\hline Chaetoceros debilis Cleve & 15 & $+t$ & ++ \\
\hline Chaetoceros gracilis Schütt & 18 & ++ & ++ \\
\hline Ditylum brightwellii (West) Grun. & 7 & ++ & ++ \\
\hline Phaeodactylum tricornutum Bohlin & 7 & - & + \\
\hline Skeletonema costatum (Grev.) Cleve & 15 & ++ & ++ \\
\hline Thalassiosira nordenskiöldii Cleve & 12 & ++ & ++ \\
\hline Thalassiosira pseudonana (Hust.) Hasle and Heimdal & 20 & ++ & ++ \\
\hline \multicolumn{4}{|l|}{ Chlorophyceae } \\
\hline Dunaliella tertiolecta Butcher & 13 & - & + \\
\hline \multicolumn{4}{|l|}{ Chrysophyceae } \\
\hline Olisthodiscus Iuteus Carter & 10 & + & + \\
\hline Pavlova $(=$ Monochrysis) lutheri Droop & 15 & ++ & ++ \\
\hline \multicolumn{4}{|l|}{ Dinophyceae } \\
\hline Amphidinium carterae Hulb. & 15 & + & ++ \\
\hline \multicolumn{4}{|l|}{ Prasinophyceae } \\
\hline Platymonas tetrathele West & 6 & + & + \\
\hline Pyramimonas amylifera Cour. & 5 & + & + \\
\hline Pyramimonas parkeae Norris and Pearson & 7 & + & ++ \\
\hline \multicolumn{4}{|l|}{ Prymnesiophyceae } \\
\hline Isochrysis galbana Parke & 12 & ++ & ++ \\
\hline
\end{tabular}

\section{Measurement of GDH activity}

GDH activity was measured by using the spectrofluorometric assay as described by Ahmed et al. (1977). In this assay, GDH activity is measured by following the oxidation of NADH and NAD(P)H at $360 \mathrm{~nm}$. The rationale being that oxidized and reduced pyridine nucleotides are differentially sensitive to destruction by acid and alkali. Acid destroys the remaining $\mathrm{NAD}(\mathrm{P}) \mathrm{H}$ not utilized in the reaction and $\mathrm{NAD}(\mathrm{P})^{+}$is converted to the fluorescent derivative by the addition of a strong base.

\section{RESULTS}

\section{Comparison of biosynthetic versus transferase assays}

Both the biosynthetic and transferase GS enzyme assays indicated the presence of GS activity in cell-free extracts from a wide variety of marine algal species comprising 6 algal classes (Table 1). Only 2 of the 15 species examined showed no significant GS activity with the biosynthetic assay. There was no apparent correlation between enzyme activity and taxonomic differences.
Exponentially growing cultures were divided in half and GS activity was compared according to the 2 assay procedures. The biosynthetic assay was found to be more sensitive than the transferase assay in terms of final product formed/assay (Table 2). However, the actual changes in optical density values were higher in the transferase assay. Another advantage of the transferase assay was that the color-development of the

Table 2. Comparison of GS activity as determined on replicate cultures by both biosynthetic and transferase assays. Biomass filtered, amount of cell extract used and incubation times were equivalent in each assay. Biosynthetic GS activity is in terms of nanomoles $\mathrm{PO}_{4}{ }^{3-}$ liberated per assay. Transferase GS activity is in terms of nanomoles of $\gamma$-glutamylhydroxamate formed per assay

\begin{tabular}{|lccc|}
\hline Species & $\begin{array}{c}\text { Bio- } \\
\text { synthetic }\end{array}$ & $\begin{array}{c}\text { Trans- } \\
\text { ferase }\end{array}$ & $\begin{array}{c}\text { Biosynthetic } \\
\text { Transferase }\end{array}$ \\
\hline C. debilis & 42 & 22 & 1.9 \\
C. gracilis & 63 & 42 & 1.5 \\
D. brightwellii & 72 & 32 & 2.3 \\
P. lutheri & 47 & 25 & 1.9 \\
S. costatum & 53 & 45 & 1.2 \\
T. pseudonana & 79 & 27 & 2.9 \\
\hline
\end{tabular}


final product ( $\gamma$-glutamylhydroxamate) was more stable than the corresponding product formed in the biosynthetic assay. The major disadvantage of the transferase assay is that it is not specific for GS (Meister, 1974).

\section{Kinetic studies of the biosynthetic GS reaction}

GS activity as a function of incubation time

The increase in GS activity with incubation time was linear for $30 \mathrm{~min}$ in all exponentially growing algal cultures examined (Table 3; Fig. 1). The fact that the intercept on the $\mathrm{X}$-axis is not at the origin indicates that there appears to be some lag period ( 4 to $5 \mathrm{~min}$ ) before we could detect any GS activity. Nonetheless, fitting the points of Fig. 1 to a power function instead of a linear fit gives a lower correlation coefficient. Thus the relationship is best described by a linear function. In 4 of the 6 species tested the activity appeared to be

Table 3 . The linearity of the biosynthetic reaction with respect to incubation time

\begin{tabular}{|lcl|}
\hline Species & Time (min) & $\mathrm{r}^{2}$ \\
\hline P. lutheri & 40 & 0.88 \\
I. galbana & 40 & 0.97 \\
T. pseudonana & 40 & 0.96 \\
S. costatum & 30 & 0.91 \\
C. debilis & 40 & 0.96 \\
T. nordenskiöldii & 30 & 0.88 \\
\hline
\end{tabular}

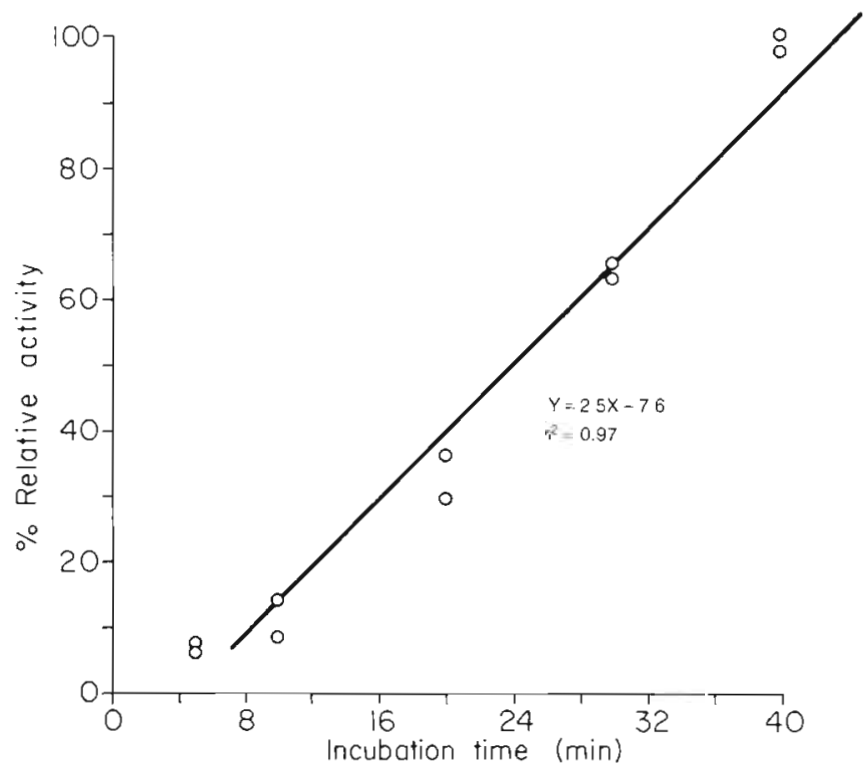

Fig. 1. Isochrysis galbana. Change in \% relative GS activity with respect to incubation time during senescent phase of growth linear for up to $40 \mathrm{~min}$. Therefore, in the optimum procedure, we incubated for $30 \mathrm{~min}$.

GS activity as a function of $\mathrm{pH}$

The $\mathrm{pH}$ optima for the biosynthetic reaction for 3 algal species, Skeletonema costatum, Thalassiosira pseudonana and Pavlova (Monochrysis) lutheri are summarized in Fig. 2. The $\mathrm{pH}$ values reported here

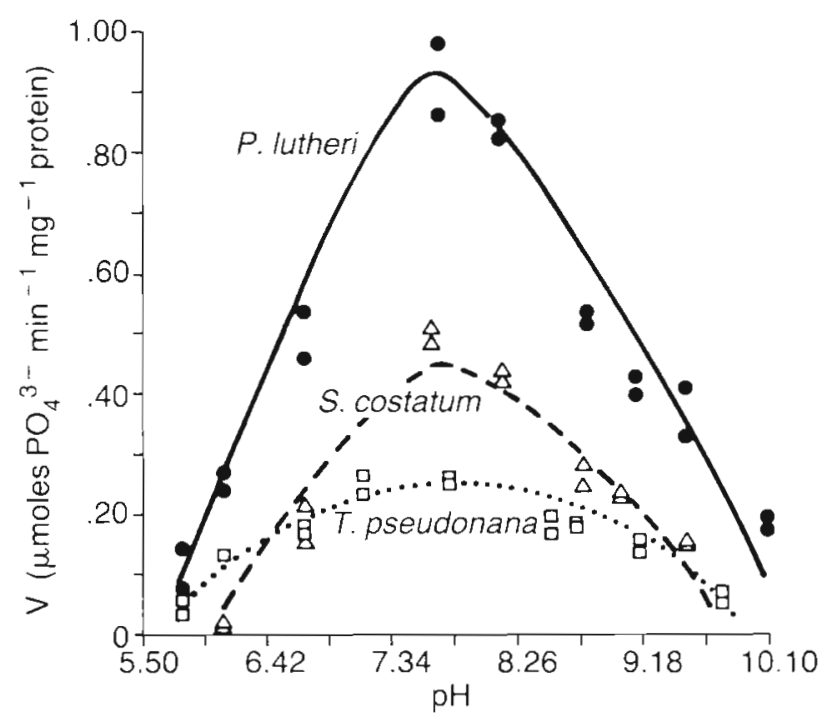

Fig. 2. Isochrysis pseudonana, Pavlora lutheri, Skeletonema costatum. $\mathrm{pH}$ optima of glutamine synthetase activity measured by biosynthetic assay with $\mathrm{Mg}^{++}$as activating cation. Cell-free extracts were used with standard assay conditions, except imidazole concentration was $0.05 \mathrm{M}$ due to addition of $0.025 \mathrm{M}$ acetate buffer and $0.025 \mathrm{M}$ glycine- $\mathrm{NaOH}$ buffer. All cultures were in the exponential phase of growth

represent the final $\mathrm{pH}$ of the reaction mixture at the end of the incubation period. All 3 species exhibited maximum GS activity in the $\mathrm{pH}$ range 7.7 to 7.8 . It was found that the glycine- $\mathrm{NaOH}$ buffer used at the higher $\mathrm{pH}$ range was not inhibitory to GS activity.

\section{GS activity as a function of temperature}

Fig. 3 demonstrates that GS activity increased exponentially up to a temperature of $30^{\circ} \mathrm{C}$ in the species tested. From this Arrhenius plot the apparent activation energies $\left(E_{a}\right)$ have been calculated by using the formula: slope $=-E_{a} / R$, where $R=$ universal gas constant $\left(1.987 \mathrm{cal}_{\text {degree }}{ }^{-1}\right.$ mole $\left.^{-1}\right)$. The activation energies determined for the biosynthetic reaction in the 3 species examined were all quite similar. A comparison of these values to the corresponding $\mathrm{GDH}$ activation energies (Ahmed et al., 1977) reveals that the GS 


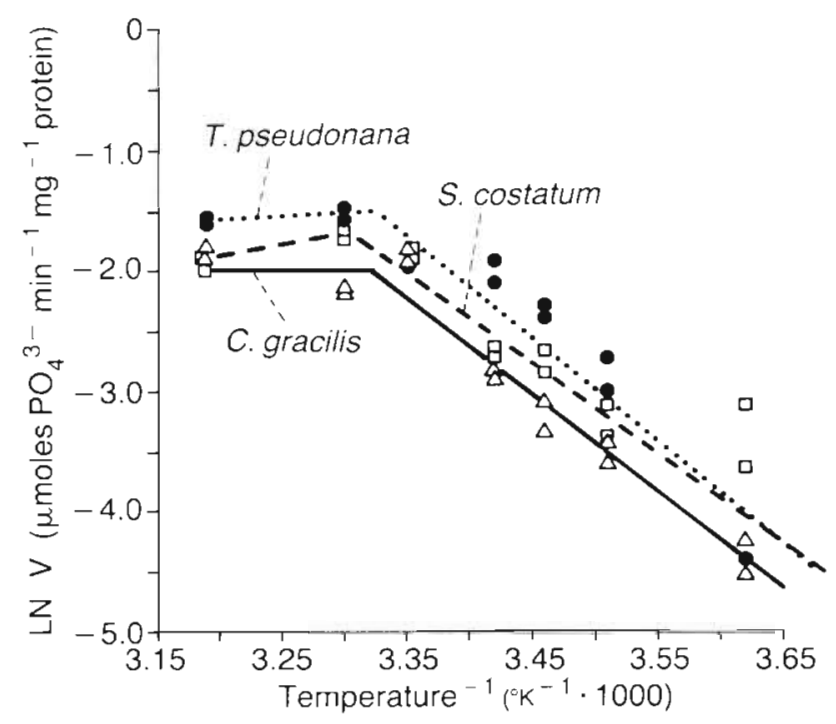

Fig. 3. Skeletonema costatum, Thalassiosira pseudonana, Chaetoceros gracilis. Arrhenius plot of data from temperature activation curves for species. Slope of individual lines yields activation energies $\left(E_{a}\right)$ : slope $=-E_{a} / R, R$ is the universal gas constant

values are slightly higher. It is reasonable to conclude that these higher activation energies determined for the GS reaction, unlike the GDH reaction, are reflective of the energy intensive nature of the former reaction process.

Interestingly, the 3 lines on the Arrhenius plot all show a slight change in slope at temperatures between 27.5 and $29.5^{\circ} \mathrm{C}$ (3.30 to 3.33 on the X-axis). These socalled 'transition temperatures' indicate when $V_{\max }$

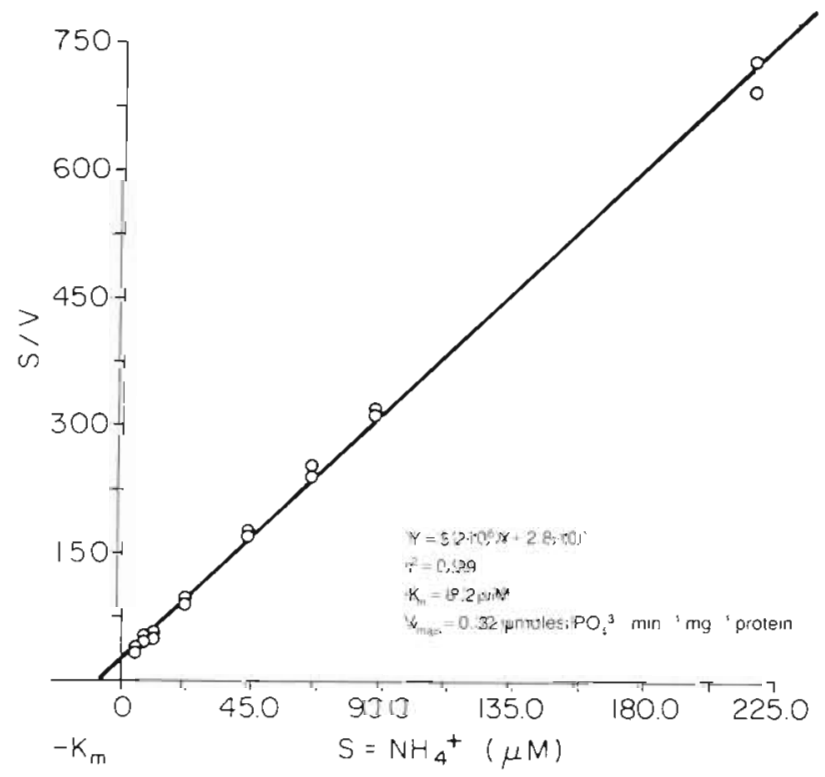

Fig. 4. Skeletonema costatum. Hanes-Woolf plot of the response of GS activity to varying concentrations of $\mathrm{NH}_{4}{ }^{+}$in exponentially growing cells
Table 4. Apparent activation energies $\left(E_{a}\right)$ based on Arrhenius plots (Fig. 3)

\begin{tabular}{lccc|}
\hline Species & $\begin{array}{c}\mathrm{E}_{\mathrm{a}} \\
\left(\mathrm{kcal} \mathrm{mole}{ }^{-1}\right)\end{array}$ & $\mathrm{r}^{2}$ & $\begin{array}{c}\text { Breakpoint } \\
\left({ }^{\circ} \mathrm{C}\right)\end{array}$ \\
\hline C. gracilis & 15.4 & 0.93 & 29.0 \\
S. costatum & 14.9 & 0.96 & 29.4 \\
$T$. pseudonana & 17.0 & 0.90 & 27.4 \\
\hline
\end{tabular}

which is regulated by the rate-limiting step, changes from one rate-limiting step to another (Segal, 1976).

\section{GS activity as a function of the various substrate concentrations}

The response of GS activity from cell-free extracts of Skeletonema costatum with respect to varying amounts of each of the various substrates is shown in Fig. 4 to 7 . All the $V_{\max }$ plots for each of the substrates have been linearized by using Hanes-Woolf transformation. These linear plots are characterized by having a slope equal to $1 / \mathrm{V}_{\max }$; the $\mathrm{Y}$-intercept $=\mathrm{K}_{\mathrm{m}} / \mathrm{V}_{\max }$ and the $\mathrm{X}$-intercept $=-\mathrm{K}_{\mathrm{m}}$. All duplicate values at each concentration tested are plotted. The coefficient of variation for each of the kinetic experiments was less than $5 \%$. The value $r^{2}$, the coefficient of determination, has been determined in most cases.

\section{GS activity as a function of $\mathrm{NH}_{4}{ }^{+}$concentration}

The response of GS activity from cell-free extracts of Skeletonema costatum with respect to varying ammonium concentrations is shown in Fig. 4. The enzyme appeared to be saturated at a concentration of $100 \mu \mathrm{M} \mathrm{NH}_{4}{ }^{+}$. The linearized data showed an apparent $\mathrm{K}_{\mathrm{m}}$ for $\mathrm{NH}_{4}{ }^{+}$equal to $8.2 \mu \mathrm{M}$. The data for all the $\mathrm{NH}_{4}{ }^{+}$-affinity experiments clearly revealed that, in all the species examined, the apparent $K_{m}$ values were in the micromolar range (Table 5). Furthermore, a comparison of the $\mathrm{NH}_{4}{ }^{+}$-affinities of GS and GDH is shown

Table 5. $\mathrm{K}_{\mathrm{m}}$ and $\mathrm{V}_{\text {max }}$ values for the substrate $\mathrm{NH}_{4}{ }^{+}$

\begin{tabular}{|lccc|}
\hline Species & $\mathrm{K}_{\mathrm{mm}}{ }^{\mathrm{app}}(\mu \mathrm{M})$ & $\mathrm{V}_{\max } \cdot$ & $\mathrm{I}^{2}$ \\
\hline I. galbana & 8.2 & 0.22 & 0.99 \\
S. costatum & 8.2 & 0.32 & 0.99 \\
C. gracilis & 4.4 & 0.19 & 0.99 \\
T. pseudonana & 1.8 & 0.39 & 0.97 \\
P. Iutheri & 7.2 & 0.51 & 0.98 \\
- Expressed in $\mu$ moles $\mathrm{PO}_{4}{ }^{3-} \mathrm{min}^{-1}$ (mg protein) & \\
\hline
\end{tabular}


Table 6. Affinity for $\mathrm{NH}_{4}{ }^{+}$for the enzymes GS and GDH

\begin{tabular}{|lcc|}
\hline Species & GS $(\mu \mathrm{M})$ & $\mathrm{GDH}^{*}(\mathrm{mM})$ \\
\hline I. galbana & 8.2 & 9.0 \\
S. costatum & 8.2 & 10.0 \\
C. gracilis & 4.4 & - \\
T. pseudonana & 1.8 & - \\
P. lutheri & 7.2 & - \\
- GDH values from Ahmed et al. (1977). Experimental \\
conditions were similar to those described under Methods \\
\hline
\end{tabular}

in Table 6. GS is saturated at $\mathrm{NH}_{4}{ }^{+}$concentrations approximately 3 orders of magnitude lower than is GDH.

\section{GS activity as a function of glutamate concentration}

GS has a rather high apparent $\mathrm{K}_{\mathrm{m}}$ for glutamate as observed in cell-free extracts of Thalassiosira pseudonana (Fig. 5). GS appeared to be saturated at concentrations greater than $120 \mathrm{mM}$ glutamate. The apparent $K_{\mathrm{m}}$ values determined for the 6 species listed in Table 7 ranged from 6.8 to $24.2 \mathrm{mM}$ glutamate. Thus the affinity of GS for glutamate was 3 orders of magnitude less than for $\mathrm{NH}_{4}{ }^{+}$. This is consistent with the observation made by Stewart and Rhodes (1977). Since glutamate serves as both the substrate for GS and the product of the GOGAT-mediated reaction, there is the possibility of excessive cycling of glutamate which would be very energy-demanding since the biosynthetic reaction requires ATP. A high $K_{m}$ for glutamate would thus reduce competition for glutamate between the enzyme glutamine synthetase and other gluta-

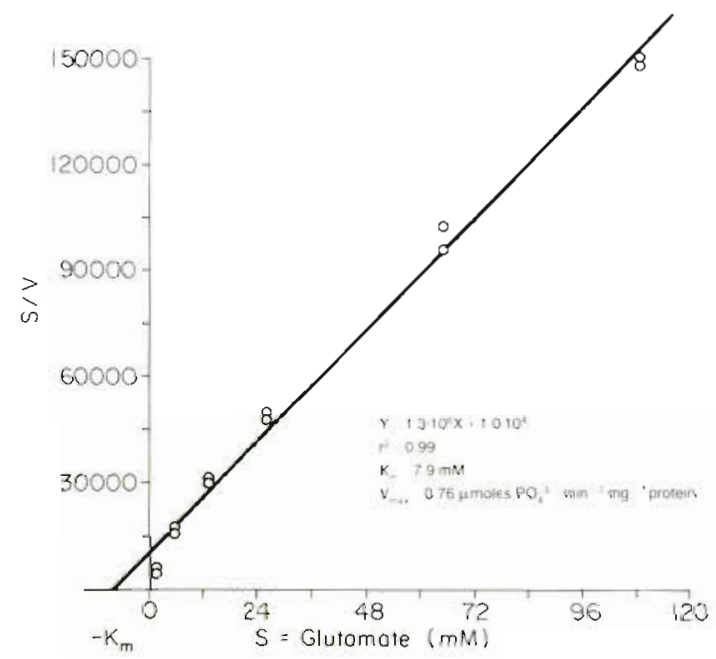

Fig. 5. Thalassiosira pseudonana. Hanes-Woolf plot of the response of GS activity to varying concentration of glutamate in exponentially growing cells
Table $7 . K_{m}$ and $V_{\max }$ values for the substrate glutamate

\begin{tabular}{|lccc|}
\hline Species & $\mathrm{K}_{\mathrm{m}}{ }^{\mathrm{app}}(\mathrm{mM})$ & $\mathrm{V}_{\max }$ & $\mathrm{r}^{2}$ \\
\hline P. Iutheri & 16.8 & 0.66 & 0.99 \\
C. debilis & 10.5 & 0.45 & 0.99 \\
I. galbana & 24.2 & 0.78 & 0.98 \\
T. nordenskiöldii & 16.2 & 1.90 & 0.99 \\
$T$ T. pseudonana & 7.3 & 0.69 & 0.99 \\
S. costatum & 6.8 & 0.76 & 0.97 \\
- Expressed in $\mu$ moles $\mathrm{PO}_{4}{ }^{3-} \mathrm{min}^{-1}$ (mg protein) & \\
\hline
\end{tabular}

mate-requiring reactions (Stewart et al., 1980). Although dual substrate kinetics were not performed, the ratio of glutamate/ATP appeared to affect the GS activity observed.

\section{GS activity as a function of ATP concentration}

Fig. 6 illustrates how GS activity varies with ATP concentration in extracts of Thalassiosira pseudonana. The enzyme appeared to be saturated at ATP concentrations greater than $2.8 \mathrm{mM}$ (Table 8 ). ATP concentra-

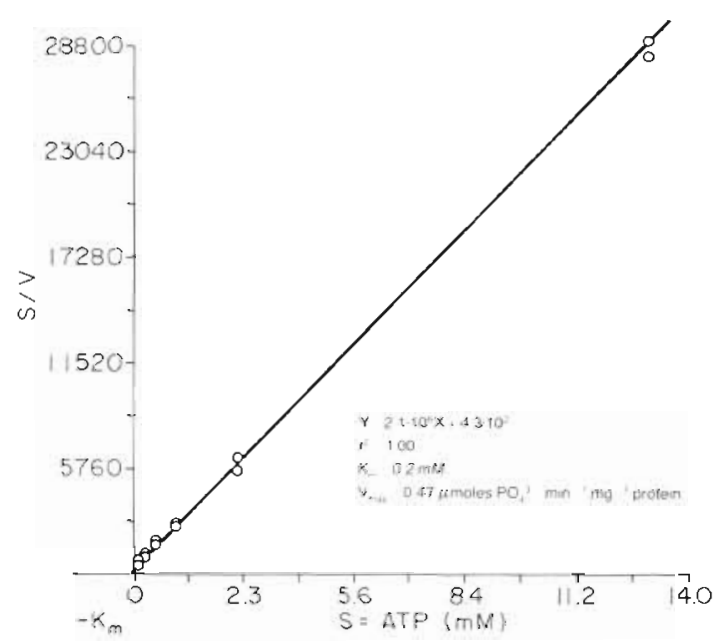

Fig. 6. Thalassiosira pseudonana. Hanes-Woolf plot of the response of GS activity to changes in the concentration of ATP in exponentially growing cells

Table $8 . K_{m}$ and $V_{\max }$ values for the substrate ATP

\begin{tabular}{|lccc|}
\hline Species & $\mathrm{K}_{\mathrm{ma}}{ }^{\mathrm{app}}(\mathrm{mM})$ & $\mathrm{V}_{\max } \cdot$ & $\mathrm{r}^{2}$ \\
\hline I. galbana & 2.10 & 1.1 & 0.99 \\
T. pseudonana & 0.19 & 0.46 & 0.99 \\
P. Iutheri & 0.20 & 0.54 & 0.99 \\
A. carterae & 0.16 & 1.70 & 0.99 \\
C. gracilis & 0.17 & 0.29 & 0.99 \\
- Expressed in $\mu$ moles $\mathrm{PO}_{4}{ }^{3-} \mathrm{min}^{-1}$ (mg protein) & \\
\hline
\end{tabular}


tions greater than $26 \mathrm{mM}$ were found to be inhibitory although the ratio of $\left[\mathrm{Mg}^{++}\right] /[$ATP $]$and not the absolute levels of each substrate appear to be more important in determining GS activity (O' Neal and Joy, 1974).

\section{GS activity as a function of divalent cation $\left(\mathrm{Mg}^{++}\right)$ concentration}

A typical response of GS activity to varying $\mathrm{Mg}^{++}$ concentrations is shown in Fig. 7 for Thalassiosira pseudonana. Throughout these experiments (Table 9) the ATP concentration was kept constant at $3.3 \mathrm{mM}$. The apparent $\mathrm{K}_{\mathrm{m}}$ values obtained by varying the $\mathrm{Mg}^{++}$ concentration in the species examined is summarized in Table 9. It extended from 2.6 to $5.0 \mathrm{mM}$. It should be mentioned here that the ratio of $\left[\mathrm{Mg}^{++}\right]$to $[$ATP] also influenced the $K_{m}$ values obtained in our studies and was found to have an optimum in the range of 0.8 to 1.5 (see also $\mathrm{O}^{\prime} \mathrm{Neal}$ and Joy, 1974). The effect of divalent cations in crude enzyme extracts has also been discussed elsewhere (Ip et al., 1982).

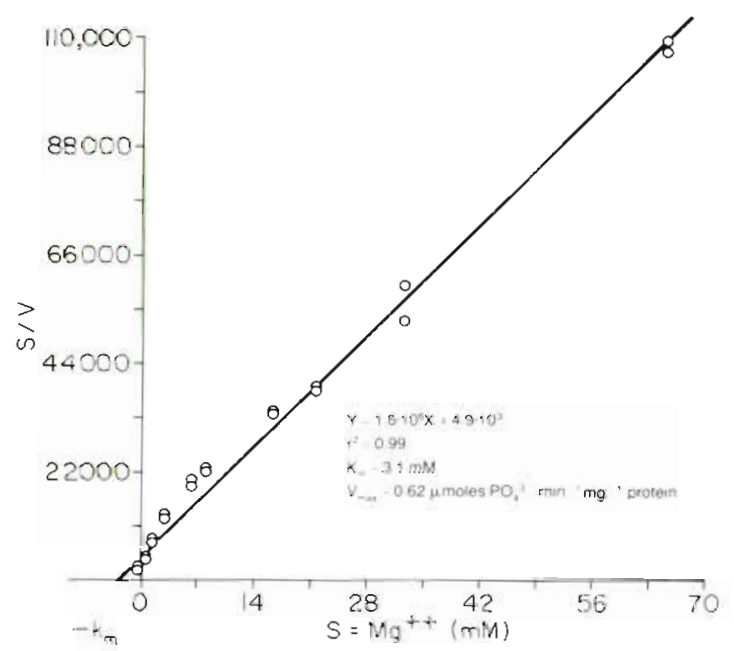

Fig. 7. Thalassiosira pseudonana. Hanes-Woolf plot of the response of GS activity to varying concentrations of the divalent cation $\mathrm{Mg}^{++}$in exponentially growing cells
Table $9 . \mathrm{K}_{\mathrm{m}}$ and $\mathrm{V}_{\max }$ values for the divalent cation $\mathrm{Mg}^{++}$

\begin{tabular}{|lccc|}
\hline Species & $\mathrm{K}_{\mathrm{ma}}{ }^{\mathrm{agp}}(\mathrm{mM})$ & $\mathrm{V}_{\mathrm{max}} \cdot$ & $\mathrm{r}^{2}$ \\
\hline T. pseudonana & 2.6 & 0.98 & 0.97 \\
S. costatum & 3.1 & 0.39 & 0.95 \\
C. gracilis & 3.0 & 0.45 & 0.99 \\
I. galbana & 5.0 & 0.59 & 0.97 \\
T. nordenskiöldii & 4.1 & 0.48 & 0.98 \\
C. angstii & 2.7 & 0.53 & 0.99 \\
. Expressed as $\mu$ moles $\mathrm{PO}_{4}{ }^{3-} \mathrm{min}^{-1}$ (mg protein) & \\
\hline
\end{tabular}

\section{Increased GS activities observed with the optimized biosynthetic assay}

Throughout the optimization procedure the concentrations of the various substrates as well as the divalent cation $\mathrm{Mg}^{++}$and the $\mathrm{pH}$ were studied as reported earlier. Having completed the substrate-saturation kinetics, the following optimal values were determined:

$$
\begin{array}{lr}
\mathrm{NH}_{4}{ }^{+} & 100 \mu l, 10 \mathrm{mM} \\
\mathrm{ATP}^{+} & 20 \mu l, 60 \mathrm{mM}, \mathrm{pH} 7.8 \\
\mathrm{Mg}^{++} & 17 \mu l, 1.67 \mathrm{M} \\
\text { Glutamate } & 100 \mu l, 1.0 \mathrm{M}, \mathrm{pH} 7.8
\end{array}
$$

Imidazole- $\mathrm{HCl}$ buffer $123 \mu \mathrm{l}, 1.0 \mathrm{M}, \mathrm{pH} 7.8$

In order to examine the effectiveness of the optimization procedure a comparative study between GS activity detected using the standard assay conditions as reported earlier versus the GS activity using the above described optimal values was undertaken. Table 10 summarizes such experiments for 2 exponentially growing cultures. One-half of each culture was assayed using the standard conditions while the other half contained the optimal values determined above. It was found that using the optimal values for $\mathrm{NH}_{4}{ }^{+}$, glutamate and ATP, $\mathrm{Mg}^{++}$and $\mathrm{pH}$, resulted in increased GS activities of 44 and $60 \%$ respectively compared with the standard assay conditions (Table 10) using supernatants of C. gracilis and S. costatum.

Table 10. Extent of optimization of the biosynthetic assay for GS activity

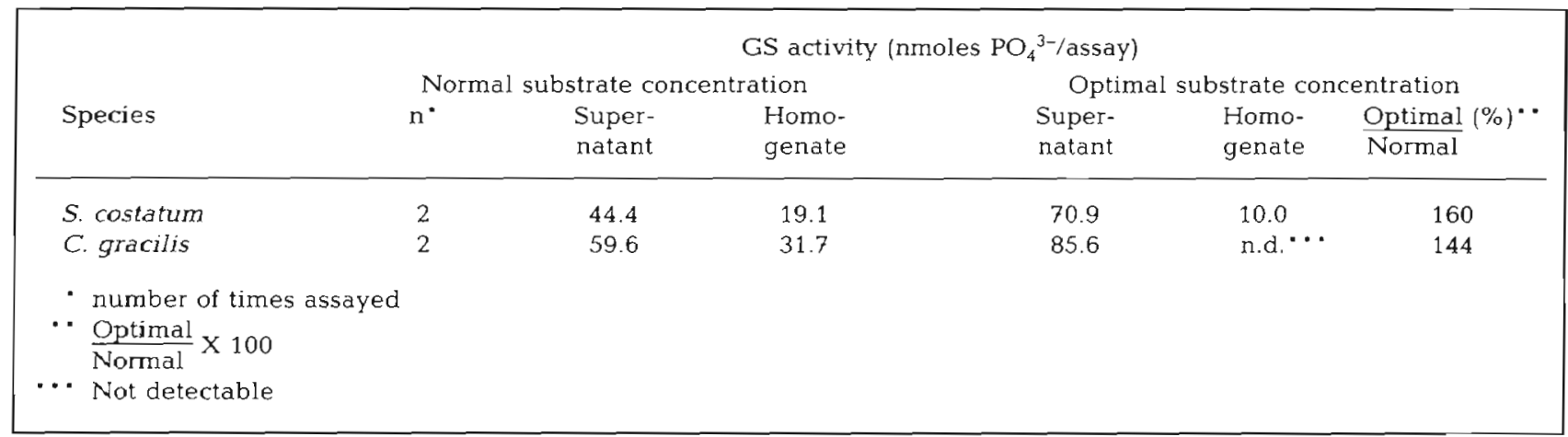




\section{DISCUSSION}

This paper is the first report of the broad distribution of GS activity in a variety of marine phytoplankton species from several algal classes. Previously GS activity has been measured in very few species of marine phytoplankton: Falkowski and Rivkin (1976) reported it in Skeletonema costatum; Edge and Ricketts (1978) in Platymonas striata; Hipkin and Syrett (1979) in Ankistrodesmus braunii; Tischner and Hüttermann (1980) in Chlorella sorokiniana, Paul and Cooksey (1981) in Chlamydomonas sp. and Sornarajah and Holdsworth (1981) in Phaeodactylum tricornutum. In all above cases, the GS activity exhibited a very high affinity (low $\mathrm{K}_{\mathrm{m}}$ ) for ammonium ions. In a dispersive environment where nutrient availability is often limited and sporadic, the need to conserve and efficiently utilize nitrogen is very important. The phytoplankton have apparently evolved diverse mechanisms to meet the challenges limiting their growth. One such adaptation is the ability of certain nitrogen-deficient phytoplankton to take-up ammonium from the environment at accelerated rates (Conway et al., 1976; Conway and Harrison, 1977; McCarthy and Goldman, 1979; Dortch et al., 1982). Another mechanism with which the phytoplankton can utilize and assimilate ammonium can be accomplished by an enzyme system which has a very high affinity for this ion. GS is an enzyme that exhibits such properties. The GS-mediated reaction thus serves as an excellent means of utilizing low levels of $\mathrm{NH}_{4}{ }^{+}$.

Stadtman (1973) proposed 2 major arguments for the predominant role played by the GS/GOGAT pathway in amino acid synthesis: (1) The GS/GOGAT pathway is driven by ATP and is essentially irreversible under physiological conditions, thus favoring amino acid synthesis; (2) the affinity of $\mathrm{GDH}$ for $\mathrm{NH}_{4}{ }^{+}$in most organisms is relatively low. Accordingly, efficient synthesis of amino acids can take place only in the presence of high intracellular ammonium concentra. tions. To maintain, at all times, a sufficiently high intracellular concentration of ammonium ions would be energetically unfavorable and possibly toxic for a marine phytoplankter confronted with growing in a very nutrient-limited environment.

If GS serves as the primary route for ammonium assimilation in marine phytoplankton, one is still confronted with the task of justifying a role for the GDH enzyme system in these same algal species. A catabolic role for GDH can be easily envisioned (Stewart et al., 1980). Often, where 2 isozyme-associated GDH enzymes have been found, 1 has been assigned a primary catabolic role (LéJohn, 1968). It is likely that in those marine species where a high level of internal ammonium pools have been found under conditions of high nitrogen availability, GDH could play some biosynthetic role (Dortch et al., 1982). Although it should be mentioned here that in an earlier study with a marine diatom, Skeletonema costatum (Dortch et al., 1979), GDH activity could account for only $5 \%$ of the ammonium uptake and assimilation rates. Rhodes et al. (1976) have reported that in Lemna minor, GS/GOGAT levels are decreased by increasing ammonium availability while GDH levels increased conversely. In this case, glutamine synthetase and glutamate dehydrogenase are subject to concurrent regulation with glutamine rather than ammonium exerting negative control on GS and positive control on GDH. It would appear, however, that although the ATP-coupled GS/GOGAT pathway is a more energydemanding reaction, such an expenditure of metabolic energy under conditions of limited nitrogen availabilty, is warranted in order to synthesize glutamine and glutamate, the key nitrogen donors for biosynthetic reactions (Shapiro and Stadtman, 1970; Tyler, 1978).

It is clear that in cases where GDH is found to possess a very high affinity for $\mathrm{NH}_{4}{ }^{+}$, this will apparently obviate the need for a functional GS/GOGAT as the primary nitrogen assimilating system. This may apply in the case of the alga Caulerpa simpliciuscula (Gayler and Morgan, 1976; McKenzie et al., 1979), as well as in Stichococcus bacillaris (Everest and Syrett, in press). The presence of GS activity in marine phytoplankton and their low apparent $K_{m}$ values appear capable of efficiently mobilizing the often limited amounts of nitrogen available in marine environments. This is in contrast to our earlier findings with the GDH enzyme. A final evaluation of the respective roles played by these 2 alternate pathways will have to await the determination of regulatory fluxes of nitrogen through these pathways under a variety of nutrient availabilities. Such studies are currently in progress in our laboratory.

Acknowledgements. This research was supported by NSF grants OCE 79-19591 and OCE 81-17937 awarded to Dr. S. I. Ahmed. This work was performed in partial fulfillment of the requirements for the degree of Master of Science for Steven Bressler, Dept. of Botany, University of Washington. We gratefully acknowledge Dr. P. J. Harrison for reviewing the manuscript and S. S. Thoresen, J. R. Clayton, Jr, and Dr Q. Dortch for their help during the course of these studies. Publication No. 1329 from the School of Oceanography, University of Washington.

\section{LITERATURE CITED}

Ahmed, S. I., Kenner, R. A., Packard, T. T. (1977). A comparative study of the glutamate dehydrogenase activity in several species of marine phytoplankton. Mar. Biol. 39: 93-101 
Bradford, M. (1976). A rapid and sensitive method for quantitation of microgram quantities of protein utilizing the principle of proteindye binding. Analyt. Biochem. 72: 248-254

Conway, H. L., Harrison, P. J., Davis, C. O. (1976). Marine diatoms in chemostats under silicate or anmonium limitation. II. Transient response of $S$. costatum to a single addition of the limiting nutrient. Mar. Biol. 35: 187-199

Conway, H. L., Harrison, P. J. (1977). Marine diatoms growns in chemostats under silicate or ammonium limitation. IV. Transient response of Chaetoceros debilis, Skeletonema costatum and Thalassiosira gravida to a single addition of the limiting nutrient. Mar. Biol. 43: 33-43

Cullimore, J. V., Sims, A. F. (1981). An association between photorespiration and protein catabolism: studies with Chlamydomonas. Planta 150:392-396

Dortch, Q., Ahmed, S. I., Packard, T. T. (1979). Nitrate reductase and glutamate dehydrogenase activities in Skeletonema costatum as measures of nitrogen assimilation rates. J. Plankton Res. 1: 169-186

Dortch, Q., Clayton Jr., J. R., Thoresen, S. S., Bressler, S. L., Ahmed, S. I. (1982). Response of marine phytoplankton to nitrogen deficiency: decreased nitrate uptake vs. enhanced ammonium uptake. Mar. Biol. 70: 13-19

Dugdale, R. C. (1976). Nutrient cycles. In: Cushing, D. H., Walsh, J. J. (ed.) The ecology of the seas. Saunders and Co., Philadelphia, p. 141-172

Edge, P. A., Ricketts, T. A. (1978). Studies on the ammoniumassimilating enzymes of Platymonas striata Butcher (Prasinophyceae). Planta 138: 123-125

Everest, N., Syrett, P. J. (in press). New phytologist. Academic Press, New York

Falkowski, P. G., Rivkin, R. B. (1976). The role of glutamine synthetase in the incorporation of ammonium in Skeletonema costatum (Bacillariophyceae). J. Phycol. 12: $448-450$

Gayler, K. R., Morgan, W. R. (1976). An NADP-dependent glutamate dehydrogenase in chloroplasts from the marine alga Caulerpa simpliciuscula. Pl. Physiol. 58: 283-287

Harrison, P. J., Conway, H. L., Holmes, R. W., Davis, C. O (1977). Marine diatoms grown in chemostats under silicate or ammonium limitation. III. Cellular chemical composition and morphology of Chaetoceros debilis, Skeletonema costatum, and Thalassiosira gravida. Mar. Biol. 43: 19-31

Hipkin, C. R., Syrett, P. J. (1977). The effects of nitrogenstarvation on nitrogen and carbohydrate metabolism in Ankistrodesmus braunii. Planta 133: 209-214

Ip, S. M., Rowell, P., and Stewart, W D. P. (1982). Effect of divalent cations on glutamine synthetase activity of Anabaena cylindrica. Abstract Soc. Gen. Microbiol. Dundee, Scotland. Vol. 9, Part 3, p. 11

Lea, P. J., Miflin, B. J. (1975). The occurrence of glutanate synthase (GOGAT) in algae. Biochem. Biophys. Res. Comm. 64: 856-862

Lea, J. A., Stewart, G. R. (1978). Ecological aspects of nitrogen assimilation. Adv. Bot. Res. 6: 1-43

LéJohn, H. B., Suzuki, I., Wright, J. A. (1968). Glutamate dehydrogenase of Thiobacillus novellus. Kinetic properties and a possible control mechanism. J. Biol. Chem. 243: $118-128$

Meister, A. (1974). Glutamine synthetase of mammals. In: Boyer, P. D. (ed.) The enzymes. Academic Press, New York, p. $699-754$

Meeks, J. C., Wolk, C. P., Thomas, J., Lockaw, W., Shaffer, P. W. (1977). The pathways of assimilation of ${ }^{13} \mathrm{NH}_{4}{ }^{+}$by the cyanobacterium Anabaena cylindrica. J. Biol. Chem. 252: 7894-7900
Miflin, B. J., Lea, P. J. (1976). Review. The pathway of nitrogen assimilation in plants. Phytochem. 15: 873-885

Miflin, B. J., Lea, P. J. (1980). Ammonium assimilation. In: Stumpf, P. K., Conn, E. E. (ed.) The biochemistry of plants. A comprehensive treatise, Vol. 5. Academic Press, New York, p. 169-202

McCarthy, J. J., Goldman, J. C. (1979). Nitrogenous nutrition of marine phytoplankton in nutrient depleted waters. Science, N. Y. 203: 670-672

McKenzie, G. H., Ch'ng, A. L., Gayler, K. R. (1979). Glutamine synthetase/glutamine: $\alpha$-ketoglutarate aminotransferase in chloroplasts from the marine alga Caulerpa simpliciuscula. PI. Physiol. 63: 578-582

O'Neal, Y D., Joy, K. W. (1974). Glutamine synthetase of pea leaves. Divalent cation effects, substrate specificity and other properties. Pl. Physiol. 54: 773-779

Pahuja, S. L., Reid, T. W. (1982). Radioisotope assay for glutamine synthetase using thin-layer chromatography. J. Chromatogr. 235: 249-255

Paone, D. A. M., Stevens, Jr., S. E. (1981). Nitrogen starvation and the regulation of glutamine synthetase in Agmenellum quadruplicatum. PI. Physiol. 67: 1097-1100

Paul, J. H., Cooksey, K. E. (1981). Regulation of asparaginase, glutamine synthetase, and glutamate dahydrogenase in response to medium nitrogen concentrations in a euryhaline Chlamydomonas species. Pl. Physiol. 68; $1364-1368$

Ryther, J. H., Dunstan, W. M. (1971). Nitrogen, phosphorus and eutrophication in the coastal marine environment. Science, N. Y 171: 1008-1013

Rhodes, D., Rendon, G. A., Stewart, G. R. (1976). The regulation of ammonia assimilating enzymes in Lemna minor. Planta (Berl.) 129: 203-210

Segal, I H. (1976). Biochemical calculations, 2nd ed. John Wiley and Sons, New York and Toronto

Shapiro, B. M., Stadtman, E. R. (1970). Glutamine synthetase (E. coli). In: Tabor, H., Tabor, C. W. (ed.) Methods in enzymology 17A. Academic Press, New York, p. 910-922

Sornarajah, R., Holdsworth, E. S. (1981). Enzymes of importance in nitrogen assimilation in the diatom Phaeodactylum tricornutum. Aust. Phytol. Workshop, p. 24

Stadtman, E. R. (1973). A note on the significance of glutamine in intermediary metabolism. In: Prusiner, S., Stadman, E. R. (ed.) The enzymes of glutamine metabolism. Academic Press, New York, p. 1-6

Stewart, G. R., Rhodes, D. (1977). A comparison of the characteristics of glutamine synthetase and glutamate dehydrogenase from Lemna minor L. New Phytol. 79: 257-268

Stewart, G. R., Mann, A. F., Fentem, P. A. (1980). Enzymes of glutamate formation; glutamate dehydrogenase glutamine synthetase and glutamate synthase. In: Stumpf, P. K., Conn, E. E. (ed.) Biochemistry of plants: a comprehensive treatise, Vol. 5. Academic Press, New York, p. $271-327$

Tempest, D. W., Meers, J. L., Brown, C. M. (1970). Synthesis of glutamate in Aerobacter aerogenes by a hitherto unknown route. Biochem. J. 117: 405-407

Thomas, W. H. (1966). Surface nitrogenous nutrients and phytoplankton in the northeastern tropical Pacific ocean. Limnol. Oceanogr. 11: 393-400

Thomas, W. H. (1969). Phytoplankton nutrient enrichment experiments off Baja, California and in the eastern equatorial Pacific ocean. J. Fish. Res. Bd Can. 26: $1133-1145$

Tischner, R., Hüttermann, A. (1980). Regulation of glutamine synthetase by light and during nitrogen deficiency in 
synchronous Chlorella sorokiniana. Pl. Physiol. 66: 805-808

Turpin, D. H., Harrison, P. J. (1978). Fluctuations in free amino acid pools of Gymnodinium simplex (Dinophyceae) in response to ammonia perturbation: evidence for glutamine synthetase pathway. J. Phycol. 14: 461-464

Tyler, B. (1978). Regulation of the assimilation of nitrogen compounds. Ann. Rev. Biochem. 47: 1127-1162

This paper was presented by Dr. M. R. Droop; it was accepted for printing on June 29, 1983 